\title{
Sensory quality and consumers' acceptance towards wild and farmed brown-trout (Salmo trutta) and farmed rainbow-trout (Oncorhynchus mykiss)
}

\section{Qualidade sensorial e aceitação pelos consumidores das trutas fário selvagem e cultivada (Salmo trutta) e arco-íris cultivada (Oncorhynchus mykiss)}

\author{
Ana Maria Antão-Geraldes ${ }^{1 *}$ (D), Sílvia Rafael Hungulo², Etelvina Pereira², \\ Amílcar Teixeira ${ }^{1}$ (D), Alfredo Teixeira ${ }^{1}$ (D), Sandra Rodrigues ${ }^{1}$ (i) \\ ${ }^{1}$ Centro de Investigação de Montanha (CIMO), Instituto Politécnico de Bragança, Campus de Santa Apolónia, \\ Bragança, Portugal \\ ${ }^{2}$ Instituto Politécnico de Bragança, Escola Superior Agrária, Bragança - Portugal
}

*Corresponding Author: Ana Maria Antão-Geraldes, Instituto Politécnico de Bragança, Centro de Investigação de Montanha (CIMO), Campus de Santa Apolónia, 5300-253, Bragança - Portugal, e-mail: geraldes@ipb.pt

Cite as: Antão-Geraldes, A. M., Hungulo, S. R., Pereira, E., Teixeira, A., Teixeira, A., \& Rodrigues, S. (2020) Sensory quality and consumers' acceptance towards wild and farmed brown-trout (Salmo trutta) and farmed rainbow-trout (Oncorhynchus mykiss). Brazilian Journal of Food Technology, 23, e2019104. https://doi.org/10.1590/1981-6723.10419

\begin{abstract}
The present study aims to compare the sensory qualities and the degree of acceptance of wild/farmed brown-trout (Salmo trutta) and the farmed rainbow-trout (Onchorynchus mykiss) by a consumer panel. Acceptability regarding attributes appearance, taste, texture, and global appreciation were evaluated on 20 wild brown-trout, 20 farmed brown-trout and 20 farmed rainbow trout by a consumers' panel formed by 74 elements. Although the panel of consumers equally well accepted all samples, the rainbow trout had classifications slightly higher in all sensory attributes. This tendency was confirmed by internal preference maps performed for each studied attribute. Consumers' slightly higher preference for farmed fish might indicate that farmed trout could be an alternative to wild brown trout.
\end{abstract}

Keywords: Internal preference map; Principal component analysis; Wild and farmed trout; Brown trout; Rainbow trout.

\section{Resumo}

O objetivo do presente estudo foi comparar as características e o grau de aceitação da truta-fário selvagem/cultivada (Salmo trutta) e da truta-arco-íris (Oncorhynchus mykiss) cultivada por um painel de consumidores. A aceitabilidade dos atributos, sabor, textura e valorização global foi avaliada em 20 trutas-fário selvagens, 20 trutas-fário cultivadas e 20 trutas-arco-íris cultivadas por um painel de consumidores formado por 74 elementos. Embora todas as amostras tenham sido igualmente bem aceites pelo painel de consumidores, a truta-arco-íris teve classificações ligeiramente 
superiores em todos os atributos sensoriais. Essa tendência foi confirmada pelos mapas de preferência interna obtidos para cada atributo estudado. A preferência, ligeiramente superior, dos consumidores por peixes provenientes de aquacultura poderá constituir uma alternativa ao consumo de animais selvagens.

Palavras-chave: Mapa de preferência interna; Análise de componentes principais; Trutas selvagem e cultivada; Truta-fário; Truta-arco-iris.

\section{Introduction}

It is a common sense that wild fish is a finite resource. However, "per capita" consumption of wild fish has been increasing over the years, and consequently the quantity of wild fish caught- both in fresh and sea waters - has been increasing over the years, being around 90 million tones since 2001. Therefore, traditional fisheries cannot meet the current consumer demand since natural fish stocks are overfished. So, aquaculture can be the most suitable alternative to traditional fishing to gradually meet consumer demand. From 2001 to 2016, according to the Food and Agriculture Organization of the United Nations (2018), there was an annual increase of $6.8 \%$ in farmed fish production. In the near future, it is expected that more than $50 \%$ of the fish that comes to the market will be from aquaculture production. Therefore, consumers will have the opportunity to buy wild or farmed fish of the same species without significant price differences (Valderrama \& Anderson, 2013). However, consumers' perceptions and beliefs, unfounded or not, concerning wild/farmed fish can influence their choices independently of the quality of fish meat (Claret et al., 2014; Rickertsen et al., 2017).

Despite the well-known aquaculture's adverse environmental impacts, this industry can have several positive impacts on biodiversity by the putative reduction of the pressure on overexploited wild stocks (Diana, 2009; Turcios \& Papenbrock, 2014). Consequently, it is essential to investigate whether or not the consumption of wild fish can be replaced by farmed fish analyzing the sensory acceptability by the consumers. This is particularly important if the consumed species have ecological value and another economic value apart from commercial fishing. Brown trout (Salmo trutta Linnaeus, 1758) is indigenous in Europe, Northern Africa, and Western Asia. In Iberia Peninsula, this species is restricted to headwaters, and it is not only important by the conservationist point of view, but it is also a valuable angling species. Nevertheless, populations are threatened by habitat degradation, inappropriate angling management practices and overfishing (Almodóvar et al., 2002, 2012). In Portugal, brown trout is not objected to commercial fishing (Portugal, 2018). However, there is an indication that poaching can be very intense in some Northern Portuguese streams. Therefore, this study aimed to compare the sensory qualities and the degree of acceptance of wild/farmed brown-trout and farmed rainbow-trout (Onchorynchus mykiss) by a consumer panel.

\section{Material and methods}

\subsection{Fish sampling}

Twenty wild brown-trout were captured by electrofishing in Baceiro River (Bragança, Portugal; 41 ${ }^{\circ} 55^{\prime} 57^{\prime}$ 'N, $6^{\circ} 50$ '55" W). Also, twenty farmed brown-trout were reared in Castrelos Fishfarm (Bragança, Portugal; $\left.41^{\circ} 49^{\prime} 28^{\prime \prime} \mathrm{N}, 6^{\circ} 50^{\prime} 49^{\prime \prime} \mathrm{W}\right)$. These late were feed with a dry extruded and pelleted commercial trout diet (AQUASOJA ${ }^{\circledR}, 40 \%$ crude protein, $16 \%$ crude lipid, $8.5 \%$ of crude ash, NEF $6.3 \%$ and $20 \mathrm{KJ} / \mathrm{g}$ gross energy), manually, once a day, 6 days a week, with a daily ration of $0.2 \%$ body mass. The wild and farmed trout were slaughtered by immersing them in a mixture of ice and water (hypothermia). This process was conducted according to Portuguese Animal Welfare (Portugal, 2000). The twenty rainbow-trout (this fish is native to North America and, therefore, no viable wild populations are found in Portugal) were brought in the local market. All fish were vacuum packaged, stored between $-18^{\circ} \mathrm{C}$ and $-20^{\circ} \mathrm{C}$, and analyzed in three weeks. 


\subsection{Sensory analysis}

In order to investigate fish preferences a randomly selected consumer's panel, with no training, formed by 74 students, professors and other staff of Polytechnic Institute of Bragança was created.

One day before the sensorial test, the samples were thawed in the refrigerator at $4{ }^{\circ} \mathrm{C}$. Since sensorial sessions were done in the afternoon, in the morning, fish were eviscerated manually through a cut in the opercular and abdominal region, from the tail to the head. Fish were then washed in tap water to remove traces of blood and viscera and $1.5 \%$ of salt was applied to each specimen. Afterward, each fish was wrapped in a previously encoded aluminum sheet and put into a preheated oven at $150{ }^{\circ} \mathrm{C}$. The cooking time was set by the time they reached $100^{\circ} \mathrm{C}$ in the innermost part of the sample. After being cooked and devoided of skin and pimples, each sample was prepared in properly standardized subsamples in pieces of approximately $2 \mathrm{~cm} / 2 \mathrm{~cm}$ and wrapped in aluminum foil and placed in a water bath for the maintenance of the temperature and properly codified a three-digit number. At least 25 consumers, in 3 different sessions, were randomly selected to participate in the sensory analysis. Samples were served individually and encoded adequately so that the panelists did not know the species they were consuming. After each sample exchange a glass of water was served to clear the taste buds. Samples were evaluated using a hedonic $10 \mathrm{~cm}$ scale $(0$ corresponded to «completely dislike», 10 corresponded to «completely like»), considering the following variables: appearance, taste, texture, and overall acceptability.

\subsection{Statistical analyses}

The one-way ANOVA test was used to assess consumers' preferences concerning attributes appearance, taste, texture, and global appreciation. To analyze if "gender" might have influenced consumers' preference for the mentioned attributes a Two-Way ANOVA was performed. The Tukey test determined significant differences. To determine consumers' preference patterns an Internal Preference Map was established. In order to obtain the Internal preference map, the acceptance data (hedonic scores) were organized in an array of samples (lines) and consumers (columns), and this was submitted to a Principal Component Analysis (PCA). The PCA identified the most important sources of variation and extracted them as components. The result is a graph where the samples are represented by letters, and the consumers are represented by points. The internal preference map generated, in a multidimensional space, the coordinates related to the product, which in turn were formed according to the consumers' responses. This statistical tool can be very useful not only to complement products description but also to indicate consumers' preference taking into account the product's sensory feature (Schlich \& McEwan, 1992).

The ANOVA was performed in the SPSS version 20 program of IBM. The internal Preference Map was obtained using the XLSTAT program, following the tutorial indicated in the Internet address of XLSTAT (PrefMap) (Addinsoft, 2019). All statistical differences were considered significant at a level of $p<0.05$.

\section{Results and discussion}

\subsection{Consumers characterization}

The most represented age range of the consumer panel was from 22 to 29 years old, representing $68.92 \%$ of all consumers. Only $8.1 \%$ were older than 40 . Most of the consumers from this panel were male (Table 1 ).

Table 1. Percentage of consumers by age and sex.

\begin{tabular}{|c|c|c|c|c|}
\hline \multicolumn{2}{|c|}{ Sex } & \multicolumn{3}{|c|}{ Age } \\
\hline 웅 & $\hat{0}$ & $18-29$ & $30-40$ & $>40$ \\
\hline 35.15 & 64.86 & 68.93 & 22.97 & 8.10 \\
\hline
\end{tabular}


Therefore, the consumer panel was mainly composed of young adults, allowing developing a preliminary sensory acceptability evaluation focused on this age group. Fish consumption levels varied considerably among panelists. Indeed, most of them consume fish once to twice a week (29.73\%). Only 10.81\% consume fish three to four times a week, and about $20 \%$ of the panel consume fish less than once a week.

\subsection{Sensory acceptability of the fish samples}

Despite of the several differences observed on fatty acid profiles and on body composition (total crude protein, lipid, ash, dry matter, and moisture) (Antão-Geraldes et al., 2019), the scores attributed to all sensory variables (Appearance, Taste, Texture and Global Appreciation) were in the indicative region of approval (values above 5 of the hedonic scale) for the three samples. Although every fish samples were equally well accepted by the panel of consumers (none of the ANOVA results showed significant differences and the classification of all samples was very close and $77 \%$ of the panelists would purchase these fish) in general, the rainbow trout had classifications slightly higher in all sensory attributes (Table 2). There were no statistical differences $(p>0.05)$ between genders regarding the sensory acceptance of the samples.

Table 2. Scores attributed by the consumers' panel to sensory variables concerning each fish species (Mean \pm SD and significance).

\begin{tabular}{ccccc}
\hline Sensory variables & $\begin{array}{c}\text { Brown trout } \\
\text { (farmed) }\end{array}$ & $\begin{array}{c}\text { Brown trout } \\
\text { (wild) }\end{array}$ & $\begin{array}{c}\text { Rainbow trout } \\
\text { (farmed) }\end{array}$ & Significance \\
\hline Appearance & $7.37 \pm 2.21$ & $6.91 \pm 2.20$ & $7.74 \pm 1.83$ & NS \\
\hline Taste & $7.27 \pm 2.21$ & $6.88 \pm 2.41$ & $7.21 \pm 2.26$ & NS \\
\hline Texture & $7.11 \pm 2.31$ & $7.35 \pm 2.06$ & $7.41 \pm 2.21$ & NS \\
\hline Global Appreciation & $7.10 \pm 2.26$ & $7.25 \pm 2.07$ & $7.41 \pm 2.06$ & NS \\
\hline
\end{tabular}

$\mathrm{NS}=$ not significant; $\mathrm{SD}=$ Standard deviation.

Nevertheless, in response to the question "What sample did you enjoy more?" - $40.35 \%$ of the panel preferred farmed brown trout, $43.85 \%$ preferred rainbow trout and only $15.79 \%$ preferred wild brown trout. This tendency was not detected in ANOVA analysis but was confirmed by internal preference maps performed for each studied attribute. Indeed, this statistic tool not only confirmed a high level of acceptance for all samples but also confirmed the consumers' higher preference for farmed fish (Figure 1). 

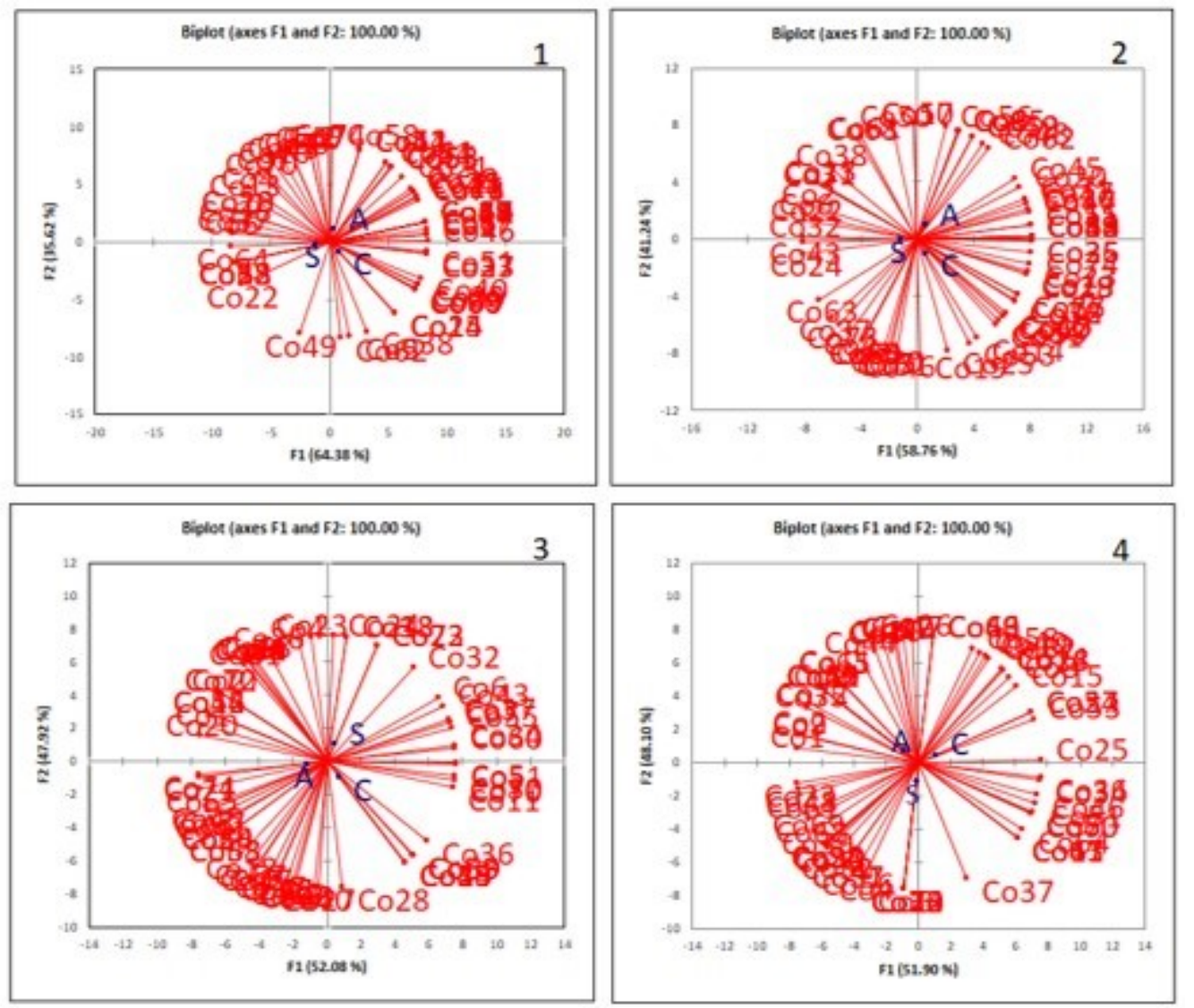

Figure 1. Internal Preference maps for the different samples $(A=$ trout-rainbow; $C=$ Captive trout; $S=$ wild trout $)$.

(1) Appearance; (2) Flavor; (3) Texture; and (4) Global Appreciation. (\% of explained variation by each factor is indicated on each graph).

This tendency was particularly notorious for "Appearance" and "Global appreciation" attributes: The lower number of the consumers located in the same quadrant on both graphics as wild brown trout confirmed the consumers' lower acceptability of this fish. However, as far as known, this statistical tool only has been used for the evaluation of fish transformed products (e.g. Green-Petersen et al., 2009), it was not possible to compare our observations with those obtained by other authors. Without using the internal preference map approach, Pohar (2011) observed that the panel created by his team had a slight preference for farmed brown trout. Ozogul et al. (2013) verified that consumers preferred wild rainbow trout. These discrepancies found among different research results might be related with both with fish intrinsic and extrinsic features (geographical origin, genotype, season, sexual maturation, age, feeding, water quality, presence of disease and parasites), which influence fish chemical composition and, consequently, fish sensory variables (taste, texture, and appearance) which, in turn, determine fish quality, consumer acceptance and commercialization (Grigorakis, 2007; Green-Petersen \& Hyldig, 2010; Oken et al., 2012; Claret et al., 2014; Suomela et al., 2016). Farmed fish sensorial quality and acceptance is also influenced phenotypic responses to the rearing environment (Goebel et al., 2017). Green-Petersen \& Hyldig (2010) found out that even fish from the same aquaculture batch can present considerable variation in fish body chemical composition. Therefore, consumers' acceptance is affected by many variables. Besides, the discrepancies mentioned above are also influenced by consumers' panel cultural, educational and socio-economics characteristics (Claret et al., 2014; Rickertsen et al., 2017). The present research brings some relevant information identifying the fish origin preferences of a sample of young adult consumers. However, establishing the sensory quality of fish and consumers' preferences is a complex process because it is influenced by a huge 
range of variables. Therefore, future research involving consumers' panels with more diversified ages and socio-economic characteristics and brown/rainbow trout from other geographical and/or rearing origins is crucial for evaluating if, in the future, it would be possible to enhance the consumption of farmed trout to avoid the depletion of the wild stocks.

\section{Conclusions}

This study, although preliminary, allowed obtaining valuable information about consumers' preferences. All the studied fish species were well accepted by the consumers' panel. Nevertheless, the internal preference map revealed that consumers showed a slightly higher acceptance for farmed brown and rainbow trout. This tool is more powerful than other statistical analyses (e.g. Ubeda et al., 2017) allowing the obtention of more accurate results concerning consumers' preferences. Given the importance of identifying food choice determinants when promoting changes in eating habits (e.g. promoting the consumption of farmed fish), this study provides the first useful insights on how to design future research approaches to deeply evaluate consumers' willingness concerning the consumption of wild/farmed trout.

\section{Acknowledgements}

The authors express their thankfulness to Centro Aquícola de Castrelos by the provision of farmed brown trout.

\section{References}

Addinsoft. (2019). XLSTAT (PrefMap). Retrieved in 2019, February 22, from http://www.xlstat.com/en/support/tutorials/prefmap.htm

Almodóvar, A., Nicola, G. G., \& Suarez, J. (2002). Effects of fishery management on populations of brown trout Salmo trutta in central Spain. In M. J. Collares-Pereira, I. G. Cowx \& M. M. Coelho (Eds.), Conservation of freshwater fishes: Options for the future (pp. 337-345). Oxford: Fishing News Books, Blackwell Science.

Almodóvar, A., Nicola, G. G., Ayllón, D., \& Elvira, B. (2012). Global warming threatens the persistence of Mediterranean brown trout. Global Change Biology, 18(5), 1549-1560. http://dx.doi.org/10.1111/j.1365-2486.2011.02608.x

Antão-Geraldes, A. M., Hungulo, S. R., Pereira, E., Teixeira, A., Teixeira, A., \& Rodrigues, S. (2019). Body composition and sensory quality of wild and farmed brown-trout (Salmo trutta) and of farmed rainbow-trout (Oncorhynchus mykiss). Ciência Rural, 48(9), e20180190. http://dx.doi.org/10.1590/0103-8478cr20180190

Claret, A., Guerrero, L., Ginés, R., Grau, A., Hernández, M. D., Aguirre, E., Peleteiro, J. B., Fernández-Pato, C., \& RodríguezRodríguez, C. (2014). Consumer beliefs regarding farmed versus wild fish. Appetite, 79, 25-31. PMid:24709486. http://dx.doi.org/10.1016/j.appet.2014.03.031

Diana, J. S. (2009). Aquaculture production and biodiversity conservation. Bioscience, 59(1), 27-38. http://dx.doi.org/10.1525/bio.2009.59.1.7

Food and Agriculture Organization of the United Nations - FAO. (2018). The state of world fisheries and aquaculture: Meeting the sustainable development goals. Rome: FAO. Retrieved in 2019, February 22, from http://www.fao.org/3/i9540en/19540EN.pdf

Goebel, S. E., Gaye-Siessegger, J., Baer, J., \& Geist, J. (2017). Comparison of body composition and sensory quality of wild and farmed whitefish (Coregonus macrophthalmus [Nüsslin, 1882]). Journal of Applied Ichthyology, 33(3), 366-373. http://dx.doi.org/10.1111/jai.13318

Green-Petersen, D., \& Hyldig, G. (2010). Variation in sensory profile of individual rainbow trout (Oncorhynchus mykiss) from the same production batch. Journal of Food Science, 75(9), 499-505. PMid:21535623. http://dx.doi.org/10.1111/j.17503841.2010.01830.x

Green-Petersen, D., Hyldig, G., Sveinsdóttir, K., Schelvis, R., \& Martinsdóttir, E. (2009). Consumer preference and description of salmon in four Northern Atlantic countries and association with sensory characteristics. Journal of Aquatic Food Product Technology, 18(3), 223-244. http://dx.doi.org/10.1080/10498850902747837

Grigorakis, K. (2007). Compositional and organoleptic quality of farmed and wild gilthead sea bream (Sparus aurata) and sea bass (Dicentrarchus labrax) and factors affecting it: A review. Aquaculture (Amsterdam, Netherlands), 272(1-4), 55-75. http://dx.doi.org/10.1016/j.aquaculture.2007.04.062 
Sensory quality and consumers' acceptance towards wild and farmed brown-trout (Salmo trutta) and farmed rainbow-trout (Oncorhynchus mykiss)

Antão-Geraldes, A. M. et al.

Oken, E., Choi, A. L., Karagas, M. R., Mariën, K., Rheinberger, C. M., Schoeny, R., Sunderland, E., \& Korrick, S. (2012). Which fish should i eat? Perspectives influencing fish consumption choices. Environmental Health Perspectives, 120(6), 790-798. PMid:22534056. http://dx.doi.org/10.1289/ehp.1104500

Ozogul, F., Yavuzer, E., Ozogul, Y., \& Kuley, E. (2013). Comparative quality loss in wild and cultured rainbow trout (Oncorhynchus mykiss) during chilling storage. Food Science and Technology Research, 19(3), 45-454. http://dx.doi.org/10.3136/fstr.19.445

Pohar, J. (2011). Detection and comparison of the sensory quality of wild and farmed brown trout (Salmo trutta) by consumers. Acta Agriculturae Slovenica, 98(1), 45-50.

Portugal. (2000, abril 22). Decreto-Lei n. ${ }^{\circ}$ 64/2000, de 22 de abril. Diário da República, Lisboa. Retrieved in 2019 , February 22 from https://dre.pt/pesquisa/-/search/522981/details/maximized

Portugal. (2018, abril 20). Portaria n 108/2018, de 20 de abril. Diário da República, Lisboa. Retrieved in 2019, February 22, from https://dre.pt/home/-/dre/115146377/details/maximized

Rickertsen, K., Alfnes, F., Combris, P., Enderli, G., Issanchou, S., \& Shogren, J. F. (2017). Consumers' attitudes and preferences towards wild and farmed fish. Marine Resource Economics, 32(1), 59-81. http://dx.doi.org/10.1086/689202

Schlich, P., \& McEwan, J. A. (1992). Cartographie des préférences: Un outil statistique pour l'industrie agroalimentaire.Preference mapping: A statistical tool for the food industry. Sciences des Aliments, 12, 339-355.

Suomela, J. P., Lundén, S., Kaimainen, M., Mattila, S., Kallio, H., \& Airaksinen, S. (2016). Effects of origin and season on the lipids and sensory quality of European whitefish (Coregonus lavaretus). Food Chemistry, 197(Pt B), 1031-1037. PMid:26675838. http://dx.doi.org/10.1016/j.foodchem.2015.11.114

Turcios, A. E., \& Papenbrock, J. (2014). Sustainable treatment of aquaculture Effluents: What can we learn from the past for the future? Sustainability, 6(2), 836-856. http://dx.doi.org/10.3390/su6020836

Ubeda, C., Callejón, R. M., Troncoso, A. M., \& Morales, M. L. (2017). Consumer acceptance of new strawberry vinegars by preference mapping. International Journal of Food Properties, 20(11), 2760-2771. http://dx.doi.org/10.1080/10942912.2016.1252388

Valderrama, D., \& Anderson, J. L. (2013). Improving the economic management of the Bristol Bay (Alaska) Sockeye Salmon Fishery in the Age of Aquaculture. Canadian Journal of Agricultural Economics, 61(2), 145-170.

http://dx.doi.org/10.1111/cjag.12007

Funding: None.

Received: Feb. 22, 2019; Accepted: Jan. 08, 2020 